\title{
Global Activism and Social Transformation vis-à-vis Dominant Forms of Economic Organization: Critical Education within Afro-Brazilian and Transnational Pedagogical Praxis
}

César Rossatto, University of Texas at EI Paso, El Paso, Texas, USA

\section{Abstract}

Masses of colonial workers are situating their free-for-all labor efforts in a global context due to dominant forms of organization based on a neoliberalist and corporate market economy. New social movements that show concern for democracy and human rights are challenging capitalist priorities of "efficiency" and exploitation. In some places, the representatives of popular movements are taking the reins of state power. Many of these movements are emerging to bridge national identities and boundaries in solidarity with transnational class, gender, and ethnic struggles. The ideology of market competition has become more entrenched in schools placing emphasis on the effects of whiteness from an historical Afro-Brazilian political experience; this article explores implications drawn upon the myriad of social struggles shaping students' lives and communities, which are based on principles of justice, ethics, access, and emancipation.

Keywords: activism, critical education, transformation, emancipation. 'race', class

\section{The Paradigms of Education Seen from a Western Imperialist Ideology}

The current paradigms for global schooling look at education with an emphasis on Western imperialist meritocratic ideologies, where the United States represents a leading force. Europe has colonized multiple countries including Latin America. The European ideology has spread by means of imperialistic power facilitated by the use of missionaries, systems of education, economic, and social stratifications. Despite stratification differences in the world, every culture ends up replicating or developing its own meritocratic model. At the same time, more and 228 | P a g e 
more configurations are beginning to collide and build similarities with the "Security State Educational Model". The main purpose of this model emphasizes how public school systems ought to produce students who can work in the global market. For example, Singapore has changed their instructional curriculum to meet the needs of the work force. The ideal of consumerism is influenced by American ideologies that are disbursing the world over through social media. Schools are being used to stress nationalism in such a way that students are developing the skills needed to become a contribution to the military force (Spring, 2009).

The values of consumerism, an educational security state, and globalization, are the new societal paradigms where students are set on conformist contentions forged by educational structures. The educational system is not meant to help people become critical thinkers, but to indoctrinate and manipulate within a far bigger exploitation paradigm. The industrialist unregulated foundation functions with high casualties; in this context, Spring (2009) suggests giving power to both educators and students in their learning as a way out of predatory capitalist entrapment.

\section{Ethics in a Globalizing World}

In a globalizing world driven by the capitalist market, corporate power dictates are the norm. To work from a disciplined and standardized viewpoint is part of the "ethical" coding, and competitiveness is the guiding force, which are often legitimized by a panoptical and third space hegemonic structure that affects the human experience from a real and imaginary standpoint (Soja, 1997). That is to say, in the US, Tea Party and Republicans' and /or Conservatives' version of ethics is based on fanatical or religious beliefs that seek to subjugate the masses through disciplinable means. This kind of ideological structure shapes human actions (or inactions), as well as social fabric development, with dehumanizing consequences. Much of these ideologies are translated into laws and policies that, in many instances, deviate from what is truly ontological ethics, just as "whatever society accepts" can be corrupted (i.e. slavery, South Africa Apartheid, Nazism, the use of modern day 
slavery labor forces, i.e., border crosser immigrants seen as "illegals," etc.).

Similarly, the implications to human existence are not about what one does wrong that affects ethical and moral conditions, but about what one becomes as a consequence of it, especially within neoliberal constraints. It is important to question:

- What are human ethics and democratic practices?

- Where can people construct together ethical modus operandi and/or modus vivendi?

- How can people exercise transformative intellectual leadership with democratic praxis, to foster citizenship and cultural responsiveness?

- How can an examination of repressive, territoriality control mechanisms reveal their impact on social constructs?

- How can alternative possibilities be organized around the notion of exercising critical questioning?

- Can a change in curriculum theory foster praxis for social justice?

These are some questions among others that are relevant to raise constantly (Rossatto, 2004).

Ethics refers to the study and development of one's values and/or ethical standards, not from a binary stand point or perspective of good and bad. Therefore, it is necessary to constantly examine one's standards to ensure that they are reasonable and well founded. It requires a continuous effort of studying our own moral beliefs and our moral conduct, and striving to ensure that we, and the institutions we help to shape, live up to standards that are reasonable and solidly-based. Ethical principles may include standards relating to rights, such as the right to have a voice, the right to freedom, the right to obligations, fairness, or specific virtues, which may imply standards that enact the reasonable obligations to refrain from crime, virtues of honesty, compassion, and loyalty, which can be supported by consistent and wellfounded reasons (Velasquez, Andre, Shanks, and Meyer, 2010). 
In this sense, new notions of solidarity and ethics should challenge postcolonial, post-modern, and post-structural practices, particularly when the desire for external rewards in one's life, rather than inward rewards, seems to be the replacement for the decline of conventional ethical principles. A conservative version of ethics is a set of induced disciplines that establish approval or disproval of conducts based on perceptions within hegemonic systems of privileges molded by those in position of power. Thus, standard conformity to ideals maintains a status- quo, lacking equity and participation of so-called "minority" groups. For example, in the US if you put all minorities (people of color) together, including women, we are the majority. So, who is, in reality, a minority? All groups that historically have been left out of history making need to see themselves as participants of their own history and not conform to being mere spectators, by challenging the lies of the status quo and demanding equity (Rossatto, 2004).

This problematic social stratum indicates that dominant groups benefit most, and disenfranchised ones are subjugated to the struggle of oblivious survival, surveillance, and silence, which in turn induce people to develop a deceitful ethic through social media. Hence, to assure all group members of a society an equal opportunity for inclusion, there is a need for critical education and transnational pedagogical praxis and a moral philosophy based on solidarity as the principle that fosters critical consciousness. It is a mutually giving and receiving experience embedded in a dialectic ethical construction, empowering citizens to participate and be responsible to each other, and it is achieved out of a commitment to the community at large where no one is left behind.

Purpel (1989) proposes that a new alternative education program facilitate active inquiry and research, contrary to an education of passivity where students are fed with a supposed given knowledge (153154). If ethics is seen as a guiding belief of a person, a group, or institutions, dictated by a structured system of moral standards, one needs to question: whose standards? Whose standards oppress others? Who is left behind? Who is most affected? Who benefits? Whose 
interests are served? Women, people of color, and indigenous populations, among other groups, have had it harder.

\section{Colonization and Transnational Historical Interpretations of the Past and Present}

Living and working along the border of EI Paso, Texas, USA and Ciudad Juarez, Chihuahua, Mexico, I have witnessed that the border functions as a thermometer of world struggles. When people experience economic and/or political struggles, more people attempt to cross the border, as in the case of Mexico, Central America, South America, Africa, and elsewhere. Recently thousands of children from Central America arrived at the US border asking for political asylum, as they were escaping violence, crime, and war. The US conservatives' narratives are to treat these children as illegal immigrants ("illegal Aliens" they say-to demonize them), rather than refugees, though they legally qualify as refugees. US laws states very clear that especially children, when entering the border ought to be given a fair opportunity to apply for refugees' status, but only those who have lawyers are properly heard in court INS Immigration hearings (U.S. Department of Justice, 2007). The violence currently experienced in Guatemala, Honduras, and El Salvador are consequence of US infiltrations in the past (in the 1980s) as well as deportations of gang members from the US, who were "dumped" in those countries, when the children no longer had family ties in those countries, since their families moved to the US during the war in the 1980s. In addition, much of these social issues are the consequence of NAFTA agreements that allows for the exploitation of labor forces in these countries (Grandin, 2014).

Another example of this kind of transnational world struggle was the Brazilian immigration to US borders during the Bush administration. Being of Brazilian nationality, I was invited to visit Brazilian immigrants who had been caught crossing the U.S. border illegally. On one occasion, working as a legal counselor volunteer, I helped 100 Brazilians who were detained by La Migra, they were all caged in one room, asking for information and desperately in need of legal assistance. This 
happened to be during the time when Brazil elected a leftist president (Lula-labeled as Marxist or Communist), while the US had a conservative President (Bush). Bush's administrative policies were particularly tough on Brazilians, handling them as though they were terrorists. They were treated differently and in a much harsher way than other detainees from other countries. I was invited as a consultant to the Brazilian government to present research for the creation of international policies to correct relations with the US and improve humanitarian practices. The new international laws proposed were adopted, and subsequently changed and improved the conditions and relationship between both countries.

Lula was elected because of an alliance achieved through several movements: liberation theology, MST (Movement of Landless Workers), Black Movement, Worker's Party, Women's Movement, among others. His leftist government was a threat to the US. At that time, before Lula's administration's improvement, Brazil was undergoing a major economic crisis. Brazil was totally colonized by economically developed countries and was subjugated by IMF control, which imposed educational programs to keep the masses ignorant. As I requested, most of the immigrants I interviewed at the border at that time wrote me a letter stating why they fled the country and how they were treated along the way. To my surprise, I found out that they were barely able to write (due to poverty and illiteracy issues), many couldn't write at all. Even now, millions of immigrants all over the world (including Europe, Asia and elsewhere) are immigrating because their educational levels are minimal and jobs for low skills levels are scarce. At the border we are able to witness world struggles, especially the exploitation of the most powerful countries and how this abuse of power over less economically developed countries reflects forced social migrations.

Historically, through the Portuguese colonizers, Brazil had enslaved three times more Africans than all of North America combined. It enslaved humans more than any other country in the Americas and it was the last one to yield abolition. The criminal traffic of Afro-enslaved people brought into Brazil against their will was utilized in order to enrich the sugar plantation's White masters. The rampant systematized crime 
experienced among the lower classes in the favelas is a consequence of the tyrannical, capitalist-induced economic conditions (Rossatto, 2011).

Nonetheless, given the opportunity to organize in the remote areas of Brazil, the Quilombos' successful activism and "struggle" mobilizations of Afro-Brazilian population allowed for immense resistance, which gave birth to uprisings in the colonizers' ranches. The Quilombos communities were composed of revolutionary militant members who had managed to escape the colonizers' enslavement. Among many inventive ways used to escape enslavement, one of the most effective ways used by the Quilombolas was Capoeira, a martial arts dance used for throwing the colonizer from his horse to the ground. History registered more than 2,000 Quilombos before 1888 (Moura 1959).

The insurrection forced the abolition of criminal enslavement in 1888; however "liberation" became conditioned to the repressive vision of White hegemony and its interpretation of freedom. It limited the Afrocommunity from accessing social rights, which forced them to gather mainly in the outskirts of urban cities, which are known today as the favelas (slums). This system evidently produced a weak social mobility system and a political submission for Afro-Brazilians, which continues to serve the economic interests of white ascendancy. This system has been condemned since 1906 by the coalitions of Black movements formed all along the country (Santos, 2000). These coalitions accomplished an expressive national articulation between 1931 and 1937 known as the Black Brazilian Vanguard (Moura, 1983). This Black Brazilian forefront, and other newly established Afro-movements, remained isolated from working-class progressive political movements because of the ideological differences that existed between them. Brazilian leftist groups (organized labor, liberation theologians, among others) and Marxists Movement would not admit an ethnically colored struggle among other social class struggles. They would, and still see, social class as the main overarching focus of struggle. Race and gender were not considered part of systematic hegemonic structures or struggles, and often they were considered to have played an inferior role (this was similar in the US labor movement and evidently in many other countries it remains an issue today, (Rossatto, Allen, and Pruyn, 2006). 
Tragically, all popular political movements were suffocated in 1937 by the Vargas military dictatorship, which also repressed the Black Brazilian vanguard. The Black movements were reconvened in 1945. In 1968 a new phase developed with a theoretical renewal, which included socialist systematic proposals. As a mobilization source and a form of political identity orientation, a cultural renewal and resurgence of sorts allowed for a re-awakening of original African cultures, which were present in the country but not accepted until then. When the military dictatorship began weakening during the early 1980s another new phase took place, which allowed for strong re-invention and re-organizing of Black movements giving birth to leftist and liberation theology oriented religious progressive movements.

During this time the development of the workers' party (PT-Partido dos Trabalhadores) solidified, concurrently the ideas of democratic and popular representations in the country were revised. Interesting to note is the beginnings of a New Leftist popular movement happened at the same time that the new Black movements took place. Evidently, this happened within an oppressive white hegemonic social structure, which kept Afro-descendants as expatriates. They were kept away from viable opportunities for upward mobility. They continued to be treated as if they were an "invisible" population, which had been an ongoing practice and something that was continuously experienced over the years.

From 1995 to the present ethnic relations in Brazil have become increasingly controversial areas of debate in academic settings as well as via mass media. This discussion intensified during the preparations for and after the International Conference on Racism in Africa in 2001. The international agenda leaned towards the need for restitution programs for African-Brazilians as a means of compensating for their loss and suffering due to white crimes. Unfortunately, due to the events of $9 / 11$, this agenda was washed out. In Brazil though, the agenda on racial issues remained present and was one of the most compelling discussions addressed in regards to the quota access of Afrodescendants into the universities. Since public universities contained a predominantly White and mostly wealthy population (89\%), which came 
from private schools, these students did not find it difficult to pass the entrance exam, called vestibular, and benefited from free public higher education. The frustrations of people of color, who are in favor of quotas, have deliberately been left out from free public university access; they usually meet this unfair and outrageous consequence with heated debates against Affirmative Action quotas by those who enjoy White privilege. Former President Lula, followed by the first female president, Dilma Roussef, had been in favor of quotas, establishing an extraordinary historical precedent that no other candidate for the presidency ever dared to address. As a candidate of the worker's party, P.T., Lula received 61.27 percent of votes, equating to 53 million votes. This marked another historical shift in Brazilian politics, leading the country from bourgeoisie conservative politics to working-class, grassroots' social democracy. Lula's campaign platform advocated for the idea that it was impossible to construct a truly democratic nation that was socially just without redeeming the immense social debt owed to the Afro-descendant population, which, historically, had made them victims of structural violence, racism, and vast injustices for over 500 years (Moura, 1983).

Still, some of the PTs elected officials, or running candidates, were able to establish better dialogue with the Afro-descendent community than with others. Nevertheless, during Lula's administration, more than ever before, Afro-descendants were finally becoming politically visible. For instance, Lula named three Afro-descendants Secretariats in his cabinet (including women and native indigenous people). During this time Lula also nominated Joaquin Barbosa, an Afro-descendent attorney to be a judge for the Supreme Court of Brazil. Barbosa was very controversial; some perceived him as someone who had internalized whiteness. However this marked an important historical shift for the country not used to seeing people of color in positions of power and privilege. Barbosa did work against the $P T$, and made questionable political judgments, culminating in the imprisonment of two iconic militant leaders, before retiring.

\section{Brazilian Worker's Party Politics and Black Movements}


The theoretical framework used here is based on U.S. and Brazilian literature in order to examine the PTs development in São Paulo, Rio de Janeiro and in the Northeast part of Brazil. Contextually presented within this work is discussion regarding the situation of "Black Brazil" today, the theoretical/historical evolution of ethnic relations, and a focus on the 1990's Black movements and their most recent advancements. Subsequently, this article examines the PTs national politics and its ethnic relations. Lastly, Lula's presidency and the confluence of interests are examined in order to finalize the analysis of Brazil's impact on the current historical world context.

This study captures narratives, as well as theoretical and literature based investigations in order to evaluate how group members construct meaning from their lived experiences. The work utilizes empirical evidence of discourses, historical fact, and its analysis. These methods best assist in answering questions such as: how does the PT contribute to the racial democratization in Brazil? What are the possible interpretations and perspectives of the Brazilian population's reactions to the quota system in a largely White hegemonic Brazil? What are the PTs shortcomings in such a struggle?

\section{The Brazilian Mestizo "Racial Model” Myth}

One of the reasons Brazilian inter-ethnic relations has become "an interesting" phenomenon to scholars is its "mestiçagem"--(racial miscegenation) quality. Many progressive theorists believe that it serves as a "racial model" for a globalized world. The myth is that Brazil, in its population composition (mulatto, cafuso, caboclo, mameluco...), is very different from any other country in the world because in Brazil there is "this beautiful" mestiçagem. The facts are treated as an exclusive phenomenon, as if other countries in the Western Hemisphere would not have similar compositions. Internationally, this faulty belief among people is conducive to an idea that in Brazil a miraculous perfection occurs that is not existent in other countries of the world. If this is the case for Brazil, that mestiçagem happens in such a remarkable manner, why then they live in such impoverished conditions? Why are NonWhites living in more difficult conditions than Whites? People of color, 
among the poorest in Brazil, occupy an even lower socio-economic status; they seldom make it to college. The poorest in Brazil are forced to migrate to transnational work places, it is usually people of color who are retained at borders; whereas the wealthy, which happen to be Whites, legally travel and immigrate internationally (Cunha, 1999).

This sort of racial ideology and its false discourse have internal and external consequences. The external translates into faulty racial terms, i.e., as a beautiful image of Brazil to the international community. The internal one intends to reduce the effects of political actions in the areas of ethnic/racial relations. On one hand, it reinforces a White leftist discourse, one that posits that Brazil's problems are concentrated on social class only; conversely, it allows Brazilian Afro-descendants the means to become unwary of identifying discrimination as systemic, or as a part of a racist system, conducive to thinking that the facts, which make people of color victims, are isolated facts. The mestizo myth is a type of thinking that promotes the idea that Brazilian ethnic relations were placated by the sexual relations of White men with Black women that is where whiteness and patriarchal discourses are not deconstructed as totalities.

The internal problem is the majority of the population believes in a naive discourse of isolated facts and translates it into a political problem of domination and aggression in a question of biological exchange without discussing the historical insight and the nature of this exchange, or the different ethnic groups' ideological localities and their social construction. The enslaved are not seen as prisoners without freedom of choice. "The mestizo in history always becomes Black,"--this position was renowned by the work of Gilberto Freire, which in his thesis Casa Grande and Senzala (translation: The Big House and the Slave House) gives total ideological coherence to the system and justifies the position of white European men and of their descendants in Brazil's history.

The methodological critique could be done taking into account that the author never examines plantation work relations, more specifically, from the point of view of those who suffered criminal trafficking in the old system of enslavement. Today, Brazilian leftists still guide themselves 
by the vision of Gilberto Freire, they continue to defend the idea that in Brazil there are no racial conflicts, thus, invalidating the existence of a black movement, or viewing it with less importance. This vision of ethnic relations via mestiçagem will continue to make it difficult, in the area of PTs formulation of ample politic regarding ethnic relations, just as it has complicated President Lula's pronouncements. The idea of "mestizoness" as a regulator of ethnic Brazilian relations is far from having been overcome, it contributes to a complex identification system regarding "racial policies" amongst Marxists and leftists, and much less amongst racist White supremacists in Brazil.

\section{Internalization of Whiteness and Racial Policies and Its Underpinnings}

According to Cunha (1999), these underpinnings, their negative references and stereotypes, ought to be deconstructed, modified, and placed order of equality to allow for dignity amongst people of some type of consciousness but who lack a deep understanding of critical race theory. Thus, in essence, what is called for here is the duty of education to deconstruct Whiteness or White privilege and/or internalized racism. At the same time it is crucially important for education and educators to address this change of consciousness in promoting anti-racism education and to resolve the deplorable living conditions of non-Whites. Consequently, it is necessary to examine the understandings on the construction of geographical spaces that are conditioned by a population's history, as well as the processes of ascendancy of present social groups. This allows for a thoughtful understanding of how social structures have been created--i.e., of gender, ethnicity, class, and the regional circumstances that have become highly intrusive on current social conditions. The lack of a broad understanding of culture, cultural wealth, and the education systems shaping them, limits students' development of a more holistic awareness of personal assets during their schooling experiences. As the realities of an emerging globalizing world continue to take shape, so too grows the need to maintain and improve social democratic practices, especially when confronted with corporate power monopolizations. Nevertheless, people of color 
continue to be subjugated and exposed to increasing risks of increasing severity.

Historically, the Brazilian reality has suffered the consequences of economic, regional, and income distribution disequilibrium, which is something experienced primarily by diverse social groups. Principally, these unequal consequences affect people according to their ethnicity, gender, social class or regional origin, provoking a correlation of these factors and presenting further ethnic cultural and regional social problems. The industrialization of the economy, developed in an unequal manner to that of the modernization of agriculture, rural work, and the unskilled technical labor force. As a result, not only did poverty increase among rural populations, but also among the large influx of migrant workers located between regions and geographic areas, which in turn produced strong socio-cultural and economic urban problems. This contributed further to the creation of a large concentration of populations (mainly people of color) that subsisted under inadequate living conditions, as seen in the urban favelas (slums) in Rio de Janeiro, São Paulo, and the Northeast quarter of Brazil.

Governmental organizations, such as IPEA (Instituto de Pesquisa Econômica Aplicada_Institute of Applied Economic Research), had published information about the evolution of ethnic and cultural inequalities and how these went hand in hand with historical reports from Afro-Brazilian social groups. In the IPEA report, a book titled Racial Inequalities in Brazil: A Balanced Governmental Intervention; written by Jaccoud and Beghin (2002) was cited as seminal. The book asserts that poverty and the lack of access to respectable citizenship can be as high as $50 \%$ for populations who are non-whites and who live under devastatingly poor conditions. This includes the indigenous populations who also deal with many difficulties on reservations and urban areas, who further suffer problems such as land conflicts, social rejection, and prejudice. The book also cites the Agrarian Reform State Office addressing the evolution of a lack of access to land in the country concurrently with the regional problematic conditions of these populations. 
Within this context, the Brazilian education system today is seeking solutions that address the diverse social groups' precarious and unequal access to schooling. It also calls for the betterment of alternative educational opportunities that address the needs of disenfranchised populations. Even though prior to Lula's government, a program called bolsa escola (public school scholarship) was created; however, the program offered inadequate assistance fees, which later increased funds to a respectable proportion.

In the area of university education, an unequal social stratum is more visible, reflecting an exclusion of minority groups or the integration of lower social classes. Among the faculty population, $98 \%$ are White, among students, $89 \%$ are White. Access to upward mobility for disenfranchised groups became still more difficult without access to university or college schooling. The report, which was based on events of the pre-national conference "Palmares Foundation-Federal Government" in 2000, indicated that the improvement of democratic practices and the attending of social demands was an intrinsic necessity for innovative research to take place in relation to inclusive university education and decent participation in citizenship (Azevedo, 2002).

The argument put forward here is that in a globalizing world, as exemplified within a Brazilian socio-economic context, issues of ethnicity are best understood when they are directly addressed. For instance, when arguments coming from non-white persons blur the distinction of skin color privilege, it demonstrates the personification of racelessness since in reality, structures, not coincidences; create a white oppressive hegemonic stratum (Fordham, 1988). To ignore or deny the historical and still present white privileges, seen as criminal, is to perpetuate oppression. History is frequently put aside, even though many university professors and well-respected journalists, popular in the national scene, present other versions of it (Massey and Denton, 1993).

The journalist Reinaldo Azevedo typifies this skewed representation in an article: The Farce of Racism in a Bad Book (Magazine First Reading Edition, No. 10, Dec. 2002); published in a magazine with a national reputation circulated throughout Brazil. Within this context, I am 
specifically addressing the social representations according to Moscovic's perspective in which a cluster of society, (the 1\%), impose their vision of reality on the masses and through systematization and legitimization of information naturalize this misconception--as if it would be applicable to society as a whole. Its content and emphasis, as per Azevedo, are repeated in several academic discourses. They are all renewed forms of ideas of Casa Grande and Senzala (Big House and the Slave Owner's House), where the relationship between dominated and dominator, is diminished in its representation, summarizing reality via simplistic, empirical statements, albeit convincingly. One example would be, "In Brazil everybody gets along well vis à vis the carnival where the poor and the rich, blacks and whites have fun together without distinction of class or race." Accordingly, social differences and their redundancy, or several forms of conflict, disappear from historical analysis. Just as unequal relationships, and the evidence and statistical data that transform history, are negated, for instance, and seen in police violence against Afro-descendant populations.

According to Gilberto Freire's analysis we have a historical simulacrum or an ahistorical, and unsubstantiated representation. Freire's work focuses on the Casa Grande and the Senzala; however, it fails to address the plight of workers where harsh labor was demanded and rendered. Freire's work also fails to consider that the system of criminal enslavement was mounted and developed for the social relations of production, and not for the work done in the Casa Grande. It leaves out the study of relations established in the field of labor, leaving out the cause of the system's violence and its ample consequences. An improper appropriation also is masqueraded. The field of labor relations, exactly the ones that Gilberto addresses so little of, explains the historical living conditions of the poor Brazilian family. It is evident in his writing that his views are meant to incite equivocations. They recognize the existent labor relations and condemn them as a social construction, but do not structure the ideas around these relations. In essence Freire establishes a center of analysis that addresses only the periphery of relations without synthesizing the system, which is the Casa Grande. In addition, Freire addresses very little about the Senzala. Since the conflicts are minimized and made of little importance, Freire's text fails to 
study also the Quilombos' uprisings. All pass as if they did not exist; moreover, it reveals deficiencies in not considering these insurrections an important aspect of the formation of the Brazilian people's collective identity. The social representations currently carried out are grounded in the re-reading of Gilberto Freire, interpreted now as anti-historical or as a simulacrum of unsubstantiated "history". This approach promotes the illusion of complete and objective analysis yet lacks criticality, it therefore is a Eurocentric perception of Brazilian society.

Thus, Gilberto Freire's influence has been widely disseminated among many members of the academic community affirming that Brazil has not had a system of racial segregation. The argument then follows that almost 400 years of criminal enslavement is not a system of racial segregation. Many have forgotten that in Brazil, work was synonymous with slavery, and slavery was synonymous with being Black. In this way, other race relations accomplish the heritage of work relations in the postabolitionist period. This consideration is not made by diverse sectors of society. To wit, Brazilian racism is widely discussed without any historical focus. The understanding under this type of ethnic optic serves as a reinforcement of the Brazilian historical character (Cunha Jr., 2001).

Furthermore, the internalization of whiteness is a phenomenon to be observed within this context, not only, in Brazil but also throughout the world. In the U.S., for instance, it is ironic to think that Colin Powell or Condoleezza Rice represent the Afro-American community, since they do not. This type of thinking reinforces the idea that because of White hegemony a person of color can indeed internalize whiteness in order to "make it". In this same way, one can understand the mestiçagem in Brazil. For a few, it is easy to think that Brazil holds an ideal racial mode without discussing, for instance, the whitening programs that all Latin American countries implement in order to strike better business deals with Europe when in reality Whites historically dominated and controlled wealth and power in colonized parts of the world. Countries, such as Argentina and Chile, went to extremes in order to exterminate all nonwhite citizens, whitening up the population with open white European 
immigration campaigns. This is another way to understand why many Brazilians have difficulties embracing their blackness.

It is necessary to understand, then, the powerful forces of white hegemony and its historical implications. For example, two decades ago, only $6 \%$ of Brazil's population chose the Negro (word officially used in Brazil) category on a national census. The majority of people prefer to choose categories like "Pardo," (dusky, a Brazilian racial diminutive). Extracting from popular narratives, people often use words such as "Bronzeado or Moreno" (sun-tinted), choices that often obscure the mestizo aspect because some Brazilian people often draw a similitude between blackness and inferiority. Many non-white Brazilians would rather prefer to be associated with white notions, as some Brazilian people are inclined to believe it provides one with a more prestigious status. Although numbers are currently changing, since Lula and Dilma's government support for Affirmative Action programs, quotas for higher education access are positively influencing Blackness and racial affirmation (Degler, 1971).

\section{Globalization, Colonization, and Neoliberalism under White Supremacy}

Though there are many agents causing neoliberal globalization, powered mainly by corporations, media, the State, and world financial organizations (such as: the World Bank, IMF, etc.), it is crucial to understand who is most exploited. Recently, economic globalization has become a major topic amongst scholars in an effort to understand and explain current political social relations. One must question then, "Who has benefited most from the establishment of recent globalization?" "How is globalization different from colonization?" This analysis concludes that race is the needed and appropriate answer. Since its inception, capitalism has been a global phenomenon entrenched in White supremacy and European imperialism. Yet, capitalism continues to be a White system of domination as most of the wealthiest people on the planet are Whites (Allen, 2001). Although this may be true globally, it does not preclude the fact that there are many white workers who are also exploited. Dehumanization in the labor force with modern day slave 
labor for wages is also part of the postcolonialities and the establishment of colonialities of power (Mignolo, Grosfoguel, and D'ussel, in Cantarino, 2012)

In Brazil, the evidence is overwhelmingly devastating, in fact, in the past only Pelé, an Afro- descendant soccer player appears on any list of Brazil's wealthiest citizens, yet not without having to have been assimilated by whiteness. Currently, White dominance operates under the philosophy of neoliberalism, which promotes the idea that the state should exercise regulatory duties and let the citizens fend for themselves. It is argued that free-market competition will equalize the playing field as a business principle in order to increase productivity at lower costs. In other words, retirement, schooling, health care, and all other social welfare programs are at the control of private efforts. As historically noted the consequences of this belief are catastrophic.

\section{Social Movements and the History of Education in Brazil}

The history of education in Brazil calls into question the prohibition of education for the enslaved during the period of criminal slavery. Africans and African-descendants managed to obtain various alternative ways of receiving their education, although in the history of Brazilian education very little reference is given to its existence.

From criminal slavery to modern day capitalism, the discussion about the education of ex-slaves is debated, however, without any measures taken. Afro-descendants reappear as a concern in education during the 1950s with the issues of universalization of education. In reality, specific governmental measures regarding the education of Afro-descendants appear in the most recent edition of the National Curricular Parameters (Brasil, 1997).

The absence of a specific concern on behalf of the Brazilian federal government, possibly, represents the confluence of two tendencies found in Brazilian culture. One is the deepening of a universalistic vision, covering up the presence of ethnic conflict in the country; and, the other is representative of a racist Eurocentric view that functions on 
the elimination of African and Indigenous cultures from an educational representation. Just in one version as in the other, the result is the expressive silencing of Afro-descendants interested in education. In recent studies, the academic research community became concerned with the educational situation of Afro-descendants, putting forward studies as of 1985 (Cunha Jr., 1999). Issues regarding Afrodescendants in education faced the bipolarization of ideas (Cunha Jr., 2001; Santos, 2000). These findings are a result of research done between 2001 and 2002 in regards to pedagogical practices and the educational positioning of Black movements. One of the concerns of such research was the conceptual problems associated with Black Movements as a social movement (Moura, 1983). In regards to this, the group prevailed as a theoretical focus resulting in domination theory, which is based on the experiences of those dominated and viewed as also related to class, gender, and regionalism. The focus on race is motivated by the struggle against racism in the daily practice of education and society. The historical aspects of racism in Brazil are recognized but operated in a structure founded on discrimination. By means of discrimination, it subsumes a discussion of gender issues. Social race, however, is not addressed; it is treated as a consequence of racism. Race is seen as a natural human condition, when in reality, social race is held as distinct of biological race, social race is the essential axle of inequalities in the country, as people are not born racist, racism is learned; it is socially constructed.

\section{Conceptual Reference}

In Brazil, studies about ethnic relations and education were initiated in the 1980s (Gonçalves \& Petronilha, 2002; Gonçalves, 1987). They were re-introduced in a similar fashion to that of the 1970s and 1980s yet with further elaboration during the 1990s, in the areas of multiculturalism, pluralism, inter-culturalism, cultural diversity, and with respect given to their differences. In these studies, the cultural categories and cultural differences, supported by policies such as that of human rights, gave voice to the social "minority" cultures whithin hegemonic majority discourses. 
The "Social Black Movement" always pointed to the necessity of recognizing Blacks as a majority population in Brazil. Souza, (1997 \&2002), with the term "Black Movement", always looks to embrace the ethnic relations in the area of social struggle of "men of color," "of negro men" and then, in the 1920s, on using the term "Blacks". There was, in the same period, some referencing to the term "Afro-Brazilians," which was used as a racial descriptor. The Black movements of the 1970s focused on a theoretical concept of class and race in order to introduce the discussion of social economic situation of the Black population inside of the perspective of social class and the process of domination (Cunha Jr., 1992). In general, along the history of the leftist political parties, the difficulties in admitting the existence of a struggle that would contemplate ethnicity and race as demarcations of capitalist exploitation is visible. The conservative sector, on the other hand, always based their presuppositions on mestiçagem and the inexistence of racism in the country as a social problem. What became established was that the problem of race in Brazil was not seen as a racial issue, but a social one (social class, in particular).

Hence, in the most recent debate, it is common for Black movements' militancy to affirm the existence of a racial problem in the country and demand from the institutions a treatment of the "racial issue". This focus on social movements from the majority of Afro-descendants is reflected in the type of concepts and studies found in writers such as Barcelos (1996), Oliveira (1992), which deal with the "social racial" category. Others, for instance, Nunes Cunha, (1999) use the term ethnicity and race, while at the same time a significant group, though of the minority, was making use of the ethnic category (Lima, 2000; Cunha Jr, 2001; Ribeiro, 2001; Solange, 2001; Cruz, 2000).

Following the establishment of gender categories as a byproduct of social relations, the "social racial" category was self-explanatory in that it was socially constructed (Guimarães, 1997). As a result, social race would not have theoretical communication with biological race. Case in point, biological race is deconstructed by science, once "social racial" is articulated it would not suffer the same attack since it does not need the biological basis for support. However, what is not easy to mediate are 
physical attributes as the definition of social race. The racial denomination is popularly accepted, enough to be made part of the social discourse, largely printed in marketing by mass media, as in the case of the magazine "Raça Brasil".

Though today anti-racist education is becoming more and more a critical goal of working class movements, Africanity was a very strong historical identity construct of the population in ascendancy in Brazil, who also suffered criminal enslavement, where capitalism sustained a racist base demarking the Afro-descendancy. When racism functions without race it is inserted into the social relations of power and domination as an ideological category. From the conceptualization of ethnicity, there are concerns with its operationalization in the theory of education. Taking into account that education has the objective of maintaining the culture and the individual's socialization, it tries to make explicit the basis of the culture or its African roots in Brazil. Subsequently, ethnicity was added as the formulation of the territoriality of the Afro-descendant's majority and the Afro-descendancy cultural repertoire (Lima, 2002). The cultural repertoire is proposed using cultural constitutional elements, identifiable and available to its utilization in the composition of educational processes. Just like proposals of ethnicity, and those of race, there are present problems of interpretation and conceptualizations. However, it was possible to build a strong foundation in education to approximate various aspects of ethnic relations (Gomes \& Silva, (2002).

The idea of social movements is widely utilized as a source of interpretation for social groups who claimed the diverse areas of public politics. In what has been done already in regards to the Black movements, and in the theory of social movements, more difficulties were to be utilized as demonstrated by analysts (Silva, 2001). The social movements during the 1970s and 1980s had a clear organization centered on issues of resource scarcity and demands for public policies of universal character. However, when the classification of Black movements was presented as a social movement it had to face theoretical challenges, since a faction of the membership did not present a formal organization and a concise character of struggle (Bianchi, 2000). 
The Black Movements added a perspective of unity around rallies of cultural identity, such as protest against racism. The unequal social, political, economic, and uneven access of upward mobility with the intent of acquiring symbolic deeds and materials is what permits the characterization of the Black movements to exist in the corpus of social movements. Given the terrain of ethnic relations without having the social groups' borders delimited is the reason of choice for the idea of social movements of majority Afro-descendancy.

\section{Black Movements and Education}

The research done in this area contains a few interesting findings. One is that Afro- Brazilian education has always been a concern of the Black movements in terms of diverse versions and politics. The focus, relative to education offered by the public and private institutions, served as a motive of some form of critique by Black movements. During the final period of transition, between criminal enslavement and racist capitalism, the struggle became the universalization of learning and the inclusion of ex-slaves in the educational system. Although not directly solicited by social movements, the state produced vocational schooling and education for the work force in "remedial programs" or "correctional facilities". In the period that follows the abolishment of slavery, the Black movements carried out incentive campaigns for Afro-descendants in education. Subsequently, in the first decades of the last century, the job market began a profound transformation. The Black movement saw in education a possibility to promote the upward social mobility of Afrodescendant's population. There were numerous incentive campaigns for education. On very few occasions, the state was criticized for the absence of a universal education.

The main change of positions of Black movements regarding education occurred during the beginning of 1970 with a critique of the racist character and Eurocentric focus of Brazilian education. It used the dropout rate, retention, and the low rates of success as evaluation resources to determine racist structures and discriminatory educational systems and practices and its policies. During the 1970s, alternative 
educational projects that centered on the self-esteem and positive identification of Afro-descendants were produced.

During the 1980s, dialogue in higher education included critiques made by Black movements, indicting higher education for being elitist and racist. Access to higher education was seen as the main problem to the production of equality in the sphere of state administration and the establishment of specific public policies that addressed issues faced by Afro-Brazilians. This paradigm of access to the university became a very important struggle. However the discussion also focused on the importance of Affirmative Action and quotas for the entrance and permanence of Afro-descendants in the universities (Andrade \& Fonseca, 2002).

During the last century, there was news about movements and educative actions in the diverse regions of the country. The states of Rio Grande do Sul, São Paulo, and Rio de Janeiro were the states where the actions of Black movements or new educational initiatives were stronger. In the last two decades, emphasis was placed on AfroBrazilian culture, the states of Bahia and Maranhão produced remarkable leadership. More recently, Quilombos events, religions of African origin, Capoeira and Hip Hop culture appear as the fruition of Black movements and serve as a focus for movements and as an educative practice. Black movements from the last 20 years have earned significant advancements in relation to issues of Afrodescendancy education, and above all in the areas of state relations. Most recently the immigration of Afro-Haitians to Brazil has raised new challenges to populations who self-define as non-racists. Forcing communities to rethink their positionalities.

\section{Lula, PT, and Brazilian Struggle for Racial Democracy and Racial Policies}

Since the beginning of Luiz Inácio Lula da Silva presidency, followed by Dilma Rousseff's, the economy in Brazil has improved tremendously. The dollar began to trade at an exchange as high as 4.00 reais and in 2013 has dropped off to about $R \$ 2.40$ 's to one dollar, which was 
considered a great success. Lula's economic policies had been well accepted internationally and most importantly, he left the presidency with an $87 \%$ favorable vote of public support; the people of Brazil approved his and the PT's governments' social policies (Brandford \& Kucinski, 2003).

One of Lula's newest social targets was to end modern-day slavery. This practice is very similar to first world countries' usage of undocumented semi-slave workers (as experienced by U.S. bordercrossing immigrant workers and "illegal" immigrants). It is always the poor, or people of color, that are exploited. In Brazil about 25,000 people work in slave-like conditions in remote jungle ranches in the states of Amazonas, Pará, Tocantins, and Maranhão. This practice is known as debt slavery, where workers are brought in and are promised a satisfactory income, but later find themselves trapped in debt since they are forced to pay more for expenses than for what they actually earn since the ranch owner owns most, if not all, small stores in the vicinity. Under serious and severe threats, anyone who attempts to leave the area is forced back. Lula's plan was to ensure state oversight and to curtail bribes given to public officials to stop them from reporting such practices. This initiative was accompanied by proposals to amend the constitution to allow the government to confiscate the farms, prosecute landowners, and give the land to the victims to work and own; in addition, they would receive education and job opportunities. More than 650 new inspectors were hired to enforce the law (Brasil, 2003).

Lula's government and the PT launched a new program called the "Zero Hunger" program. He used the symbolism "campaign" of US/British war/occupation on Iraq to generate support for the program, using slogans like "this is a war that is worth fighting for". He also proposed an international fund to end hunger in the world based on a simple rule: "for every dollar spent on war, $10 \%$ must go to the hunger fund".

A publicity campaign began the day after the US/England invaded Iraq, with radio and TV ads and the placement of inserts in newspapers. The ads used an anti-war strategy, much as the ones used in the U.S., to campaign amongst the public to enlist their support for the war. The 
campaign in Brazil is very touching as it evokes empathetic feelings to end hunger. The slogans would say, "this is our war" (meaning the war against hunger). There is a great deal of expectation and popular support for the program, with donations from campaigns among the people and large companies' offering their services pro bono. The program is implemented as a pilot project in the state of Piauí (North East). However, about 150 cities would be taking part in the near future, to then increase the number to 1,000 by the end of the year (Pires, 2003).

Lula's government also offered workers a $20 \%$ increase in the minimum wage, which was a major improvement. Lula and the PT promised, during the election campaign, to double the existing minimum wage within four years. This is very significant, especially for one third of Brazil's population who live in poverty. At the end of Lula's term, about 32 million were helped out of poverty, leaving 18 million more behind, which Dilma's presidency accepted as a first priority for her government term (Portal Brasil, 2013).

Brazil's history of criminal enslavement also explains the widespread discrimination suffered by Afro-Brazilians today, which represents about half the country's population of close to 200 million people. Since getting into office, Lula had shown favorable insights and demonstrated concerns with the betterment of the Afro-populations plight with unjust social conditions. In January 2003, two policies had been implemented. The first one was the promulgation of a new law from the Education State Department (law of 9/01/2003) that obligates the inclusion of Africa's history and Afro-Brazilian culture in the curricula for elementary and junior high students. The second one installed to office a cabinet for the "Promotion of Racial Equality in the Government Civil House".

Neither initiatives came with ample instruction about the manner in which the policies would be executed their implemention then was unorganized.

Conversely, looking at the most recent developments, one can see that historically the political action of Black movements in the 1990s has gained considerable national expression. They reinforced the demands 
for public policies and increased the visions about the necessity of insertion of Afro-Brazilians in the machine of government.

In 1988, the federal government recognized the necessity of an official office or institution that would coordinate cultural policies with the education of Afro-Brazilians. Its duty was to give answer to the demands derived from the Black movements. The struggle forced the government to create new initiatives to address their concerns, which gave origin to the Palmares Cultural Foundation in the Culture State Office. Given the scarcity of funding, this foundation always existed under precarious conditions. Multiple functions, besides the culture, comprised the incumbency given by government itself along the lifespan for this task. In this way, the foundation always focused attention and dissatisfaction between Black movements and Federal Government relations. The large pressures on the federal government by the Black Movement appear in the first turn of Cardoso's presidency. In 1995, the entire country paid homage to the anniversary, 300 years, of Zumbi's death (a liberator and an anti-enslavement hero) and gave a national and public dimension to the demands of the Black Movement.

To this day, Zumbi of Palmares is held in high regard for his contribution as one of the most important revolutionary leaders during the period of criminal enslavement in Brazil. He had become a symbol of the struggles for the populace in the Black movements since the mid-1970. Palmares was one of the biggest Quilombos in Brazil's history. Later, it constituted a republic of cities, which were parts of the territories conquered by Palmares; this lasted for almost seventeen centuries (Freitas, 1978). Palmares is the most distinctive and the longest held example of popular resistance in the history of the Americas. A movie was made describing this history, known as Quilombos, and is internationally available, it depicts the importance of this event. Though its historical significance is recognized, Quilombo still lacks more advanced historical and archeological studies.

The activities of 1995 were concluded with a national rally in which 20,000 militants from the Black movements walked to Brasilia. The 
participants started the rally walking from different regions of the national territory, having some coalitions traveling more than 3,000 kilometers.

The rally held strong ties to all progressive sectors of Brazilian society, in particular, from unions such as Central Única dos Trabalhadores (CUT). The rally organizers gave the president and the senate president a document further exposing the situation of Afro-descendants in the country and demanding action be taken to address issues of employment, public policies, health care, better living conditions, education, social communication, and the fight against institutional racism, it called for the reclaiming of the Quilombos' land. As a response, the federal government put into operation a new interstate department office called Grupo de Trabalho Interministerial (GTI), which quickly became obsolete and inoperative. Nevertheless, the Brazilian government recognized officially, for the first time, the existence of racism in the country and instructed a few governmental branches to conduct some work concerning this predicament. The recognition resulted, towards the end of the second turn of Cardoso's presidency, in an elaboration of quota policies, reflected in part by the federal public branches. The discourse spread and gained momentum in relation to the practices and the discussion of income of Afro-descendants in public universities, centralizing its debate in the media, it was during the Lula administration that new initiatives finally took place.

The Lula da Silva presidency inherited from Cardoso's government a number of immense problems that were practically not touched upon since 1995, but that had political ramifications and public policies implications. Two problems were fundamentally notable: one, the conflict of land ownership and recognition of Quilombos' land; two, the urban issues of the majority of the Afro-descendants living in the favelas (slums). The absence of upward social mobility for the Afro-descendant population is part of the structural spectra, which became acute in Cardoso's era by the privatization of state government companies.

The change that occurs during Lula's government is a rupture between the particular and the universal. The installation of the new Cabinet for the Promotion of Racial Equality in the Civil House, and the inclusion of 
some Black personalities in the highest and most important political functions, point out the elaboration of specific policies to Afrodescendants. It is a difficult change given the fact that several sectors of the PT (worker's party) do not incorporate in their programs the necessity of such specificity.

In conclusion, Lula's presidency followed by Dilma's, allowed for the conceptual advancement of Black movements but has yet to be consolidated further. To change hegemonic structures is easier said than done, but the unprecedented is viable and possible. Above all, the internalization of white supremacy is more a white problem than an issue of non-whites. Non-whites are on the receiving end of the problem, victimized by oppressive systems (policies and structures). On the other hand, prejudice constructed and conceptualized because of a lack and/or limiting source of information can be an issue for most human beings. Nonetheless, in whiteness as an internalized racist social construction, only those born in the system of privilege benefit from it, and are perpetuating their sense of false superiority. It is possible to transform the pattern of oppression and inherited privilege by first deconstructing whiteness and colorblindness, with anti-racist pedagogy and curriculum, to then develop racial democracy consciousness and culturally responsive pedagogy. Only after it becomes a permanent historical structure, which includes white consciousness transformation, is it possible to unlearn such beliefs and relearn new ways that bring about racial social justice. From the perspective of non-whites, what is required is a pedagogy of indignation, which allows for the use of appropriate anger in regards to the struggle. This fight requires ontological hope to change what is preconceived as impossible, or immutable, since the "impossible" is only what never had been before attempted.

Hence, at this instance of Lula and Dilma's presidency, which continues to unfold as recent street protests have demonstrated, it seems that the first initiatives could be effective and are expected to head in the right direction. Nonetheless, the overcautious measures and the lack of specific policies also indicate a lack of appropriate articulation inside of PT's constituency as a still evolving political party. To be certain, they 
could use any assistance they might receive. The invisible is becoming visible, and racial equality and democracy seems a possibility yet only results and outcomes can change White hegemonic oppressive structures. It is the "oriented outcomes", that guarantee diversity.

After deconstructing the colonizers' internalized racism, it makes sense to implement multiculturalism as an everyday practice. For institutions deeply and seriously committed to the spirit of racial equality, the intent to build diversity is not enough, only the results proven historically really count (Rossatto, in Cavalleiro, 2001).

\section{REFERENCES}

Allen, R. L. (2003). Letter: affirmative Action in need of revision. Daily Lobo. UNM May 19.

Andrade, R. \& Fonseca, E. (2002). Aprovados!: Cursinho pré-vestibular e população negra. São Paulo: SP, Brazil. Selo Negro Edições.

Azevedo, R. (2002). The Farce of Racism in a Bad Book. Magazine First Reading Edition, number 10, Brasilia: December.

Barcelos, L. C., (1992). Raça e Realização Educacional no Brasil. Rio de Janeiro. IUPERJ, (Dissertação, Mestrado em Sociologia).

Barros Ribeiro, R. M., (2001). Trajetórias de Formação de Professores

Frente a Complexidade das Relações Étnicas no Cotidiano

Escolar. Tese de doutoramento UNICAMP Campinas - SP.

Bell, D. (1992). Faces at the bottom of the well: The permanence of racism. New York: NY. Basic Books.

Bianchi, A. (2000). Plantando Axé: Uma proposta pedagógica. São Paulo: SP, Brazil. Cortez.

Brandford, S. \& Kucinski, B. (2003). Politics Transformed: Lula and the worker's party in Brazil. London: UK. Latin America Bureau.

Brasil, (2003). Lei Federal No. 10.803. In:

http://www.planalto.gov.br/ccivil_03/leis/2003/l10.803.htm

Cantarino, C. (2012). Brazilian Postcolonialities. Portuguese Cultural Studies, Fall 2012, No. 4.

Carone, I. \& Bento, M. (2002). Psicologia social do racismo: Estudos sobre branquitude no Brasil. Petropolis: RJ, Brazil. Editora Vozes.

Cruz, M.S. (2000). A História dos Estudos Sociais a Partir das

Representações do Negro no Livro Didático. Período 1981-2000. Mestrado - UNESP- Marília - SP. 
Cunha Jr., H. (1999). Educação Afrodescendente em Mestrados e Doutorados. Alguns Comentários e uma tentativa Bibliográfica. Anais do XIV Encontro de Pesquisa Educacional do Nordeste: Avaliação Institucional. G.T. 03 - Movimentos Sociais e Educação. CD-ROM. Sonopress-Rimo Ind. E Com. Fonográfica Ltda. NEHP/CPD/UFBA.

Fordham, S. (1988). Racelessness as a factor in Black students' school success: Pragmatic strategy or pyrrhic victory? Harvard Educational Review, 58(1), 54-84.

Freitas, D. (1978). Palmares a Guerra dos Escravos. Rio de Janeiro: Edições Graal Ltda.

Degler, C. (1971). Neither black or white: Slavery and race relations in Brazil and the United States. New York: NY. Macmillian.

Gomes, N. \& Silva, P. (2002). Experiências Étnico-Culturais para a Formação de Professores. Belo Horizonte:MG, Brazil. Autentica Editora.

Goncalves, L. \& Silva, P. (2002). O jogo das diferencas: O multiculturalismo e seus contextos. Belo Horizonte: MG, Brazil. Autentica Editora.

Gonçalves, E. \& Silva, P. (1987). Educação e identidade de negros trabalhadores rurais de limoeiro. Porto Alegre: Tese de Doutoramento. Faculdade de Educação. UFRG.

Gonçalves, L. \& Oliveira, A. (1985). O silêncio: um ritual pedagógico à favor da discriminação racial: um estudo da discriminação racial como fator de seletividade na escola pública de primeira à quarta série. Belo Horizonte, UFMG,. Dissertação de Mestrado em Educação.

Grandin, G. (2014). Interview with Noam Chomsky on the Crisis in Central America and Mexico. The Nation. October 31, 2014. Guimaraes, A. S. (1997). Racismo e Anti-racismo no Brasil. Tese de Livre Docência. FFLCH - USP. São Paulo.

Lima, M. B. (2001). Mussca- Laranjeiras, "O Lugar do Preto Mais Preto": Cultura e Educação em Territórios de Predominância Afrodescendentes Sergipanos. Dissertação de Mestrado. UERJ. Rio de Janeiro.

Lima, M. B. \& Cunha Júnior, H. (2002). Repertórios Culturais de Base africana, Identidade a afrodescendentes e educação em Sergipe. In Multiculturalismo e Pedagogia Multirracial e Popular. Cadernos do NEN - Núcleos de Estudos Negros. Volume 08. Dezembro. Pp. 63-94. 
Massey, D. \& Denton, N. (1993). American Apartheid: Segregation and the Making of the Underclass. Cambridge, MA. Harvard University Press.

Mahalingam R. \& Mccarthy, C. (2000). Multicultural curriculum: New directions for social theory, practice, and policy. New York: NY. Routledge.

Moura, C. (1959). Rebeliões na Senzala. Rio de Janeiro: São Paulo. Edições Zumbi. Moura, C. (1983). Organizações Negra em São Paulo.IN: Brasil: As Raízes do Protesto Negro. São Paulo: Global. Moses, M. (2001). Affirmative Action and the creation of more favorable contexts of choice. American Educational Research Journal. Spring, vol. 38, No. 1, pp.3-36.

Munanga, K. (1999). Redisutindo a mestiçagem no Brasil:Identidade nacional versus identidade negra. Petrópolis: Editora Vozes.

Nunes Cunha, L. (1999). Educação, Afrodescendentes e Modernidade 1920-1930 no Estado de Pernambuco. Recife: Dissertação de Mestrado. UFPE.

Oliveira, R. (1992. Relações Raciais na escola: uma experiência de intervenção. São Paulo. Dissertação de Mestrado. PUC.

Pires, C. (2003). Lula convoca país para operação de guerra contra fome. UOL Ultimas Noticias. 30/01/2003.

Portal Brasil, (2013). Em 10 anos, Bolsa Família tirou 36 milhões pessoas da extrema pobreza. Ministerio do Desenvolvimento Social, (Cidadania e Justiça). In:http://www.brasil.gov.br/ cidadania-e-justica/2013/09/em-10-anos-bolsa-familia-tirou-36milhoes-pessoas-da-extrema-pobreza

Ribeiro, M. S. (2001). O romper do silencio: Historia e Memória na Trajetória Escolar e Profissional dos Docentes Afrodescendentes. Tese de Doutoramento. USP. São Paulo - SP.

Rossatto, C. A. (2004). Social Justice in Times of McCarthyism Renaissance: Surveillance, Ethics, and Neoliberalism. In Social Justice in These Times. (O'Donnell, J., Pruyn, M., and Chavez Chavez, R. Eds.). Greenwich, Connecticut: Information Age Publishing Inc.

Rossatto, C.A. (2011). Schooling Future Oppressors: Teaching Global Communities about White Privilege. (Rossatto, C.A. Ed). Information Age Publishing.

Rossatto, C. A., Allen, R.L., and Pruyn, M. Eds., (2006). Reinventing Critical Pedagogy: Widening the Circle of Anti-Oppression

Education. Boulder, Colorado: Rowman \& Littlefield Publisher, Inc. Rossatto, C. (in Cavalleiro, 2001). Racismo e anti-racismo na educação: Repensando nossa escola. São Paulo: SP, Brazil. Summus. 
Santos, J. A. (2000). "Raiou a Alvorada": intelectuais negros e imprensa. Pelotas (1907 - 1957). Niterói, RJ. Dissertação de Mestrado. Universidade Federal Fluminense.

Soja, E. W. (1997). Thirdspace: Journeys to Los Angeles and other real and imagined places. Transactions of the Institute of British Geographers. Vol 22 Issue 4; pp 529-540, December.

Souza, T. C. V. (1997). Com a Palavra o movimento negro: contestando o racismo e desmistificando a democracia racial. Recife:

Dissertação de Mestrado. UFPE.

Souza, N. (2002). Tornar-se negro: As vissicitudes da identidade do negro brasileiro em ascenção social. Rio de Janeiro: RJ, Brazil. Edições Graal Ltda.

Souza S. (2002). Para onde vai a democracia? Caros amigos. Guarulhos: SP. Editora Casa Amarela;\#15. Nov.

Spring, J. (2009). Globalization of Education: An Introduction. New York, NY: Routledge Taylor and Francis Group.

Tatum, B. (1997). "Why are all the Black kids sitting together in the cafeteria?" and other conversations about race. New York: NY. Basic Books.

Twine, F. (2000). Racism in a racial democracy: The Maintenance of white supremacy in Brazil. New Brunswick: NJ. Rutgers University Press.

M. P. (2001). O Anti-racismo no Brasil: considerações sobre o estatuto social baseado na consciência racial. São Paulo: Revista Psicologia Política. Ano 1, vol. 1, n. 1. Pp. 37-65. . (1992). Textos para o movimento negro. São Paulo. Edicon. (1998). Afrodescendência Pluriculturalismo e Educação.Revista Pátio. Ano 2. Num.6. Ago/out., p.21-24.

- (2001). Africanidades, Afrodescendência e Educação. Revista Educação em Debate. Fortaleza. Ano 23 Vol.2 num 42; 2001 pp 5-15. (ISSN 0102-1117).

U.S. Department of Justice, (2007). Operating Policies and Procedures Memorandum 07-01: Guidelines for Immigration court Cases Involving Unaccompanied Alien Children. David L. Neal (Chief Immigration Judge). May 22, 2007.

Velasquez, M., Andre, C., Shanks, T. S.J., and Meyer, M. J. (2010). What is Ethics? Issues in Ethics IIE V1 N1 (Fall 1987); Revised 2010.

Wise, T. (2000). Acknowledging and Challenging Whiteness. AlterNet. July 3.

\section{Author Details}


César Augusto Rossatto, Ph.D. is Associate Professor at the University of Texas at El Paso. He is author of numerous publications including: Engaging Paulo Freire's Pedagogy of Possibility: From Blind to Transformative Optimism. He is founder of Paulo Freire SIG at AERA (American Education Research Association) and founder and chair of the International Conference on Education, Labor and Emancipation (http://academics.utep.edu/confele). A UCLA graduate with specializations in critical pedagogy, critical multiculturalism, education for justice, and the sociology of education. Rossatto is committed to dialectic and dialogical education and praxis for the liberation of disenfranchised groups. Rossatto extends and reinvents Paulo Freire's work; critical temporal theory; the social context of education; organizational politics; international and urban education; and has a deep familiarity with U.S. and Latin American cross-cultural issues. His main research interests are Ethics; religious influences and immigration; the U.S. and Mexican border within the context of Globalization and Neo-Liberalism, social relations; and Brazilian identity formation in the United States and its implications to schooling. Rossatto specializes in the phenomenon of fatalism and optimism in contrast with social class differences, as well as the effects of global racism. He is an international spokesperson and a senior publishing editor. 